\title{
Muslim Converts Understanding the Textual and Contextual Muallaf
}

Mohammad Ridzuan Abdul, Salasiah Hanin Hamjah, Mohamad Zulkifli Abdul Ghani

To Link this Article: http://dx.doi.org/10.6007/IJARBSS/v11-i6/10186

DOI:10.6007/IJARBSS/v11-i6/10186

Received: 07 April 2021, Revised: 10 May 2021, Accepted: 29 May 2021

Published Online: 13 June 2021

In-Text Citation: (Abdul et al., 2021)

To Cite this Article: Abdul, M. R., Hamjah, S. H., \& Ghani, M. Z. A. (2021). Muslim Converts Understanding the Textual and Contextual Muallaf. International Journal of Academic Research in Business and Social

Sciences, 11(6), 580-588.

\section{Copyright: (c) 2021 The Author(s)}

Published by Human Resource Management Academic Research Society (www.hrmars.com)

This article is published under the Creative Commons Attribution (CC BY 4.0) license. Anyone may reproduce, distribute, translate and create derivative works of this article (for both commercial and non-commercial purposes), subject to full attribution to the original publication and authors. The full terms of this license may be seen at: http://creativecommons.org/licences/by/4.0/legalcode

Vol. 11, No. 6, 2021, Pg. 580 - 588

Full Terms \& Conditions of access and use can be found at http://hrmars.com/index.php/pages/detail/publication-ethics 


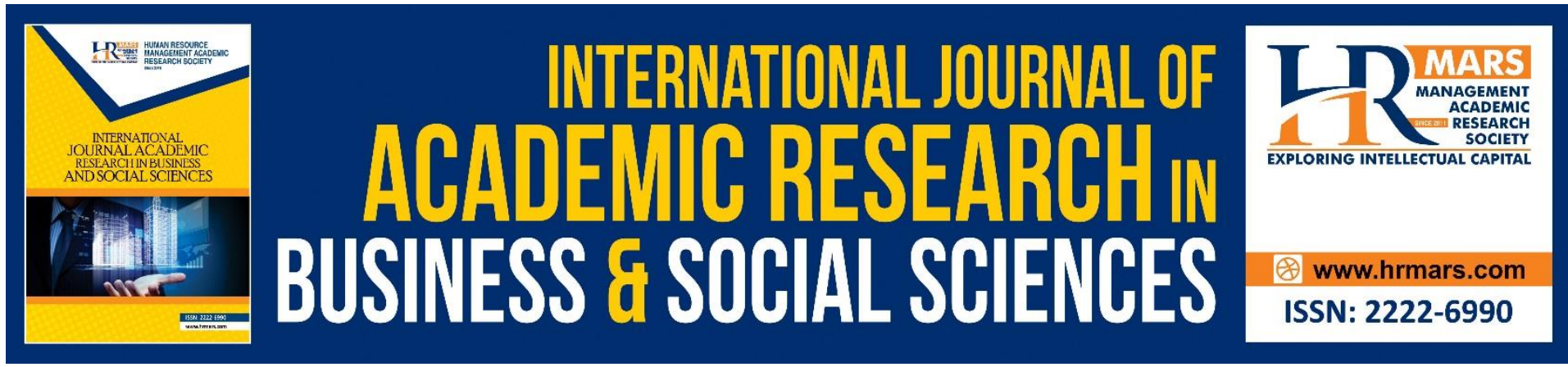

\title{
Muslim Converts Understanding the Textual and Contextual Muallaf
}

\section{Mohammad Ridzuan Abdul, Salasiah Hanin Hamjah, Mohamad Zulkifli Abdul Ghani}

Centre for Da'wah and Leadership studies, Faculty of Islamic Studies, National University of Malaysia.

Email: p106353@siswa.ukm.edu.my, salhanin@ukm.edu.my, zulghani@ukm.edu.my

\begin{abstract}
There converts who fail to understand converts textually and contextually. The failure causes them to continue to think that they are still converts and entitled to receive help from certain organization. This study was conducted to discuss the understanding of textual and contextual converts in Negeri Sembilan. It is a qualitative study with an analytical design. Data collection methods used for this study were document analysis and interviews. Results of the study showed that convert do not understand the actual term of "convert" and the time limit to be known a convert. Lacking knowledge related to this matter, has negative impact to the parties involved in providing assistance to converts, especially religious agencies. This study is expected to provide an explanation to the converts the true meaning of the "convert" and there rights.
\end{abstract}

Keywords: Understanding, Muslim Convert, Textual, Contextual, Convert

\section{Introduction}

Textual is closely related to the content of a text as a whole. While contextual is a person processes new information or knowledge (True, 2021). Textual and contextual converts, refer to the overall issues related to converts, including the conversion to Islam, registration, the period of fatwa, their rights and others.

As it is known, converts are amongst the eight asnaf groups who are eligible for assistance from Islamic Religious Agencies. The terms convert are widely discussed and have various meanings from various perspectives. As in the words of Allah SWT in surah AtTawbah verse 60 regarding the concept of convert according to Islam.

The meaning,

"Zakat is only for the poor, and the needy, and the amils who collected Zakat, converts and to those who are in debt, due to commitment towards Allah SWT".

This Quranic verse in surah At-Tawbah explains about the asnaf zakat group and the fourth group is the muallaf group (Khafidz, 2006). The concept of muallaf in terms of language is derived from the words qulub and hum. Qulub comes from qalaba, yaqlibu, qalban which means to reverse or change the outside inwards (Khafidz, 2006). 
According to Ibn Manzur in Lisan al-'Arab muallaf is interpreted allafa which carries various meanings. Among them is number a thousand, collecting something from one another and composing books (Manzur \& Makran Ibn Manzur al- Afriqi al-Misri, t.th). According to alMarbawiyy, it refer to a person who is new (embracing) Islam. While in terms of terminology is much debated in the four sects and among them, Mazhab Syaf'iyy defines to a convert.

The term is also debated and is combined and adapted to contemporary conditions. Among the views from al-Qaradawiy which means people Non Muslims are inclined toward Islam (Al-Qaradawiyy; Abdullah, Yusuf;, 2000). This group of converts can qualify themself to receive assistance and zakat as stated in the Quran (Fazrul, 2015).

According to the Administration of the Religion of Islam (Negeri Sembilan) Enactment 2003, section 108 states that 'a person converted to Islam and becomes a Muslim as soon as he has finished reciting the two words of Syahadah provided that the requirements of section 107 are met; and the person is afterwards referred to as a convert and the convert is known as muallaf after reciting the syahadah. Muallaf will be a normal Muslim after a period of set time. While for a person who exceed the period of conversion set by each state in Malaysia, they are normal Muslim and there is no difference with other Muslims who are Muslims from birth.

\section{Problem Statement}

Studies related to the period of converts are rarely discussed by the community. As such, researchers see it as a serious issue regarding the status and term limits of converts. There is an issue in Berita Harian Online in June 2016 entitled the status of converts should be limited. According to the Senior Lecturer of the Faculty of Syariah and Law, Universiti Sains Malaysia, Assoc Prof Dr Azman Ab Rahman in the Berita Harian said, if the time limit for converts is not limited, then these converts will continue to receive assistance even if they have a permanent jobs and cause injustice to the distribution of zakat.

Data from the Department Dakwah of the Negeri Sembilan Islamic Religious Affairs Department (JHEAINS) shows that there are still converts who seek assistance from religious agencies. They still thinking that they are still converts and deserve assistance. Following is the data of muallaf from the Dakwah Division of the Negeri Sembilan Islamic Religious Affairs Department (JHEAINS) which shows the recipients of general assistance from religious agencies by race in January to July 2020. 
Table 1. General Assistance Recipients Data by Race from January to July 2020

\begin{tabular}{lll}
\hline Bil & Race & Recipients of Assistance \\
\hline 1 & Chinese & 42 \\
2 & Indian & 102 \\
3 & Sabah & 5 \\
4 & Sarawak & 9 \\
5 & Foreigner & 4 \\
6 & Orang Asli & 22 \\
7 & Others & 8 \\
\hline
\end{tabular}

Source: Department of Dakwah Negeri Sembilan Islamic Religious Affairs Department 2020

Discussion from the 108th Fatwa Committee Muzakarah of the National Council for Islamic Religious Affairs Malaysia, for Islamic Religious Affairs Malaysia convened on 2-3 November 2015 has decided that the maximum period for a muallaf 5 years. However, there are states that do not have time limit namely Perlis and Kedah. Meanwhile, the state that has time limit is Pahang which is 6 years and followed by the states of Penang, Selangor, Negeri Sembilan, Melaka and Sabah for 5 years. The state of Perak is for 3 years while the states of Kelantan, the Federal Territories and Johor have no time limits (Malaysian Islamic Development Website, 2020). 
Table 2. Recognition for Muallaf by State

\begin{tabular}{|c|c|c|c|}
\hline No & State & & Duration \\
\hline 1 & $\begin{array}{l}\text { Jawatankuasa } \\
\text { Kebangsaan }\end{array}$ & Fatwa & None (local script) \\
\hline 2 & Perlis & & None \\
\hline 3 & Perak & & 3 years with the condition to join the religion class \\
\hline 4 & Kedah & & None \\
\hline 5 & Pulau Pinang & & 5 years \\
\hline 6 & Selangor & & 5 years \\
\hline 7 & Negeri Sembilan & & 5 years \\
\hline 8 & Melaka & & 5 years \\
\hline \multirow[t]{2}{*}{9} & \multirow{2}{*}{\multicolumn{2}{|c|}{ Johor }} & No period (education) \\
\hline & & & $\begin{array}{l}\text { Financial \& medical consolation: according to the } \\
\text { qualification limit of converts }\end{array}$ \\
\hline 10 & Pahang & & 6 years \\
\hline 11 & Terengganu & & No period \\
\hline 12 & Kelantan & & No period \\
\hline 13 & Wilayah Persekutua & & Not stated \\
\hline 14 & Sabah & & Maximum period of 5 Years \\
\hline 15 & Sarawak & & $\begin{array}{l}\text { None (those who have converted to Islam for many years } \\
\text { are no longer recognized as converts) }\end{array}$ \\
\hline
\end{tabular}

\section{Source: Website e-smaf JAKIM}

Following the 108th Fatwa Committee Muzakarah of the National Council for Islamic Religious Affairs Malaysia, Negeri Sembilan through the Negeri Sembilan Mufti Department number 3/2016 which convened on 31 March 2016 agreed to set a maximum term limit for a muallaf 5 years (official website of the Malaysian Islamic Development Department, 2020).

Muallaf will be provided with assistance by religious agency during the 5 years period. Assistance as the follow:

\section{Education}

Education is a pillar in producing useful human beings, intellectually in terms of emotion, spiritual and physical. Through education, it is also able to remove society poverty (Abd Rahman \& Mohd Din, 2015). This coincides with the government's efforts to make education an obligation to muallaf without making financial as an obstacle (Rahman, et al., 2015). The hadith from Prophet Muhammad SAW which is related to seeking knowledge is demanded in 
Islam. As the Prophet SAW said in Sunan Ibn Majah, Kitab Sunnah: 23/27: 224 means, "Seeking knowledge is an obligation on every Muslim".

The religious agencies through Islamic Religious Council (MAINS) and Negeri Sembilan Islamic Religious Affairs Department (JHEAINS) strive to create a group to assist for converts. This group serves to help manage the administration of muallaf and documentation, teach the basics Islamic understanding, make reports on the performance of muallaf for improvement, manage the welfare of muallaf others. The modules provided are structured modules where the teaching begins with the basics of Islam and is taught in stages according to the level of understanding of the group. This module helps muallaf to understand Islam after embracing Islam.

\section{Financial}

Just as education is important, financial stability can provide comfort in life. In this era of globalization, everyone wants financial stability. Zakat statistics in 2019 show the distribution of zakat by state. Selangor shows the highest recipients followed by the Federal Territories and Kedah (Department of Wakaf, Zakat and Hajj, 2021). At the same time, financial assistance given to muallaf are monthly, aidilfitri assistance and others. The purpose of this assistance is to help them start a business or start a new life within the muallaf period.

In Negeri Sembilan, according to the Head of the Muallaf Excellence Unit, (Abdullah, 2021) in an interview with him, he said that among other assistance given and received by muallaf are consolation, basic assistance, monthly assistance, scholarships, household assistance and wedding consolation. The assistance provided is in the form of incentives for survival. However, after the period of 5 years of the muallaf, can apply for assistance under other zakat asnaf such as asnaf fakir, miskin and others. Recipients of there assistance must make an application and attach the necessary documents to facilitate the responsible party to ensure that this group is indeed eligible for assistance.

\section{Religious Classes}

Muallaf are new and in need of guidance and encouragement from the authorities. The presentation should also be appropriate and suitable for the muallaf. The Islamic Religious Council (MAIN) or the Department of Islamic Religious Affairs (JAIN) will provide study classes to muallaf.

As a result, many muallaf are obligated to participate in such classes have been organized by MAIN and JAIN. Courses related to the introduction of Islam which includes aspects of monotheism, theory and practice on the implementation of prayers, obligatory bathing and others (Bakar \& Ismail, 2018). These classes are not only done on a monthly basis but also on a weekly basis through continuous supervision. However, the implementation of this class will differ according to the state regulations in terms of time, language, location of the teaching (Zamry , Zulkifli, Lubis, Che Noh, \& Abd, 2019).

The Department of Islamic Development Malaysia (JAKIM), MAIN AND JAIN have collaborated in creating an official portal of muallaf known as e-muallaf introduced in 2013. This portal gather data regarding muallaf throughout Malaysia and provides many facilities to the muallaf in obtaining information regarding studies and guidance from time to time.

\section{Research Methodology}

This study is a qualitative study designed to analyse content. Data collection methods were performed with document analysis and interviews. The analysis of this document was taken 
from previous studies. Sufficient data and analysis are associated to this study. Data collection using this qualitative method is necessary to understand the phenomena which is related to this study. This interview was conducted with the Head of the Muallaf Excellence Unit at the Negeri Sembilan Islamic Religious Council (MAINS), Dr. Adnan Abdullah who is responsible in carrying out the scope and functions related to muallaf and is also responsible for managing their cases in Negeri Sembilan. Apart from that, interviews were also conducted with Jasni Ajom's muallaf from the Temuan tribe, Mrs. Norhaslinda Chia Abdullah, honorary secretary for the Malaysian Chinese Muslim Association (MACMA) Negeri Sembilan branch, Mrs. Dhia Nuraisyah Ng Abdullah a civil servant and Mrs. Nor Sofia Bobby Abdullah. Their joint interviews will provide additional information to this study and answer some of the questions that may arise.

\section{Results of the Study and Discussion}

\section{Muallaf 'Understanding of the Textual and Contextual Muallaf}

Muallaf given who recite two words of syahadah is provided in section 108 of the Administration of the Religion of Islam (Negeri Sembilan) Enactment (Enactment, 2003) and the term limit for calling muallaf has also been set up to five years through Muzakarah Jawatankuasa Fatwa Negeri Sembilan number 3/2016. However, some of the new muallaf are not aware of the duration because it is a fatwa that has just been decided.

Muallaf' misunderstanding of the term muallaf is closely related to the society and the environment that call them by various terms. According to (Rahman, et al., 2015) muallaf is nowadays considered and termed by the local community with Muslim brothers, new brothers and our brothers an effort to reach out to this group. There is no denying that the purpose is good because Allah SWT also demands to acknowledge others with good name, as he says in Surah al-Hujurat verse 11 which means,

"O you who believe! Let not a party (of men) scoff and despise another tribe of men, (because) the party that is despised could be better than them: and let not a party of women mock and despise another tribe, (for) should the despised the tribe could be better than they; and let not one of you reveal the shame of the other; and do not call one another by evil titles. (These prohibitions cause the person who does it to be wicked) it is very bad to mention the name of the wicked (to someone) after he has believed. And whoever does not repent, then they are the wrongdoers".

The study found out that some muallaf do not understand the exact call for them as stated in the enactment and fatwa. This can be evidenced through a joint interview (Abdullah NC, 2021) the honorary secretary of the Malaysian Chinese Muslim Association (MACMA) Negeri Sembilan, (Abdullah, 2021) who has embraced Islam for almost 10 years and (Abdullah, 2021) who has embraced Islam more of 20 years who say many of the new muallaf do not understand the term muallaf. This is due to the fact that no specific term is given to those who are muallaf for more than 5 years.

The study also found out that there are also muallaf who know and understand the term muallaf. According to (Ajom, 2021) who has embraced Islam for more than 25 years stated that he understands the term muallaf and the time period, though in the early stages of muallaf this matter was not mentioned. He also suggested that the term Muslim brother be used for those who have come out of the period.

Some new muallaf think they are muallaf forever after embracing Islam. As a result, they demand their help and rights as asnaf muallaf their status pros, lack of knowledge, welfare quality them to receive assistance from authorities. There muallaf have tendancy to 
reverse to their previous religion. Religious agencies such as MAINS and JHEAINS will be burdened because not all of them are in need of such aid. As a result, MACMA also assists the agency in providing information and understanding to muallaf regarding the status and their rights. This is proven because MACMA in the state of Kelantan also provides assistance and services from various aspects such as obligatory classes and advanced guidance classes to muallaf (Fatah \& Tan Ai Pao @ Tan Abdullah, 2018).

The Malaysian Islamic Welfare Organization (PERKIM) also provides welfare assistance to new relatives. This coincides with the main goal of its establishment to carry out all missionary work, education, welfare including providing assistance, donations, scholarships to those who are qualified and providing help for the sick and the needy (Tan Ai Pao @ Tan Abdullah, Kadir, Tibek, \& Abdullah, 2012). The researcher found that most of the muallaf did not understand the term muallaf in the early stages of their conversion to Islam due to the lack of exposure given on the matter. Just matter has also not be raised.

\section{Conclusion}

This study found out that there are some muallaf who do not know that the muallaf has a time limit, especially in Negeri Sembilan. They are still confused with the right call for them when the muallaf period is over. Some informants suggested some specific terms to be used as it seem fit to them.

This study can help muallaf to understand more accurately the the term muallaf as well as to know the specific period that qualifies them to still be called muallaf. Disclosure, textual and contextual emphasis of the term muallaf to those who have just uttered the two words of syahadah should be given attention by the authorities and relevant NGOs. In addition to that explaining the rights and privileges for muallaf are constrained by time as stipulated by the fatwa.

\section{Corresponding Author}

Mohammad Ridzuan bin Abdul

Research Centre for Dakwah and Leadership Faculty of Islamic Studies National University of Malaysia, Malaysia.

Email: p106353@siswa.ukm.edu.my

\section{Reference}

Al- Quran.

Abdullah, A. (2021). Kefahaman tentang istilah muallaf. (R. Abdul, Interviewer) Negeri Sembilan.

Abdullah, D. N. (2021). Kefahaman tentang istilah muallaf. (R. Abdul, Interviewer) Negeri Sembilan.

Abdullah, N. C. (2021). Kefahaman tentang istilah muallaf. (R. Abdul, Interviewer) Negeri Sembilan.

Abdullah, N. S. (2021). Kefahaman tentang istilah muallaf. (R. Abdul, Interviewer) Negeri Sembilan.

Abdullah, T., Abdul Kadir, F. A., Tibek, S. R., \& Abdullah, A. (2012). Program dakwah Islamiah Pertubuhan Kebajikan Islam Malaysia (PERKIM) kebangsaan kepada saudara muslim: satu tinjauan dari segi pendidikan. International Conference on Research in Islamic and Arabic Language Education 2012 (ICRIALE 2012), (pp. 374-382). 
Bakar, S. A., \& Ismail, S. Z. (2018). Pengurusan mualaf di Malaysia kerjasama dinamik antara agensi kerajaan dan bukan kerajaan. Journal of Islamic Social Science and Humanities, 16: 133-155.

Ajom, J. (2021). Kefahaman tentang istilah muallaf. (R. Abdul, Interviewer) Negeri Sembilan.

Al- Qaradawiyy, Y. (2000). Fiqh al- Zakah. In Dirasah Muqaranah li Ahkamiha wa Falsafatiha fi Daw' al- Qur'an wa al-Sunnah. Beirut: Muassasat al-Risalah.

Berita Harian Online. (2016). Status mualaf perlu dihadkan. Berita Harian Online. Retrieved Disember 20, 2020

Enakmen. (2003). Enakmen pentadbiran agama Islam (Negeri Sembilan). Bahagian ix memeluk agama Islam. seksyen 108. saat memeluk agama Islam.

Fatah, M. A., \& Abdullah, T. (2018). Keberkesanan program dakwah MACMA Kelantan terhadap muallaf. Jurnal At-Tahkim, 8(25):6.

Fazrul, W. M. (2015). Indeks pengukuran penentuan had tempoh mualaf di Malaysia. Jurnal Infad, 6: 40-63.

Sembilan, J. H. E. A. I. N. B. D. (2015-2019). Statistik muallaf di Negeri Sembilan. Negeri Sembilan.

Wakaf, J., Haji, Z. D. J. (2021). Jabatan Waqaf, Zakat dan Haji (JAWHAR). Retrieved from Laman Web Rasmi Portal Pengurusan Maklumat Zakat dan Baitulmal Malaysia: http://baitulmal.jawhar.gov.my/zkt_agihan_stat.php

Khafidz, H. A. (2006). Asnaf Lapan: Kesan Nilai Semasa dan Setempat dalam Menentukan Penafsirannya di Malaysia. Tesis Ph.D, Jabatan Fiqh dan Usul, Akademi Pengajian Islam, Universiti Malaya.

Manzur, I., \& al- Afriqi al-Misri, M. M. I. M. (t.th). In Lisan al-'Arab. Beirut: Dar al- Bayrut.

Rahman, A. A., Subri, I. M., Mutalib, M. A., Dali, M. N. R. M., Razali, W. A. W., Ibrahim, R. I., . . . Ismail, N. (2015). Penerimaan penggunaan istilah mualaf dalam kalangan mualaf di Malaysia. Majallah Idarah wa Buhus al-Fatawa, 6: 111-134.

Rahman, A. A., \& Din, A. S. M (2015). Bantuan zakat untuk pendidikan kepada asnaf: Kajian di Negeri Sembilan. Proceeding of The International Conference on Masjid, Zakat and Wakaf (IMAF 2015). Shah Alam, Selangor.

True, M. (2021). Contextual Learning. Retrieved from k12academics.com: https://www.k12academics.com/alternative-education/contextual-learning

Majah al-Qazwini, Y. I. M. (t.th). Sunan Ibnu Majah. In Kitab Sunah, al Muqaddimah. Canada: Darussalam.

Zamry , A. F., Zulkifli, H., Lubis, M. A., Che Noh, M. A., \& Abd, A. H. (2019). Hubungan konsep rahmatan lil'alamin dan bantuan kebajikan terhadap mualaf. Proceeding of The 12th International Workshop and Conference of Asean Studies in Islamic and Arabic Education, Linguistics, Social Science and Educational Technology. Bangi, Selangor. 